\title{
Astronomy, Literary Criticism, and Medieval Literature: An Introduction
}

1. On the celestial ascent in Chaucer's House of Fame see Swinford, "Stellification” and Daemon's Gate. On aerial voyages in early modern literature, and their ancient influences, see Maus de Rolley.

2. It is unlikely that Christine had encountered the House of Fame directly. See Coletti.
Despite misconceptions about an incurious or unscientific Middle Ages, the literatures of medieval Europe abound in astronomical speculation and enquiry. Voyages through the cosmos and visions of the Earth in space recur as narrative devices in both learned treatises on natural philosophy and in poetry. The prevailing literary genre for writing about the stars and those who looked up at them was the philosophical dream vision, which usually centred on a vertiginous ascent among the stars that granted the dreamer, usually a poet, an elevated perspective on the Earth they leave behind. In Geoffrey Chaucer's House of Fame (c.1380), his dream persona is seized by an enormous and very talkative eagle, who carries the poet skywards until he finds himself "Flowen fro the ground so hye / That al the world, as to myn ye, / No more semed than a prikke" (House of Fame 2.904-07). As the ground falls away beneath them, the eagle urges the poet to "cast up thyn ye," and "se yonder, loo, the Galaxie, / Which men clepeth the Milky Wey" (2.935-37), all the time lecturing the frightened poet on the stars and their relation to poetry. ${ }^{1}$

Written only a couple of decades later, Christine de Pizan's Le Chemin de Longue Étude ("The Path of Long Study") (1402-03), is also a dream vision that centres on a guided ascent to a place among the stars, but while Chaucer ascended "wyth fetheres of Philosophye" (1. 2.975), Christine uses a ladder. ${ }^{2}$ Christine's dream persona is led by the Cummaean Sibyl, who had guided Virgil's Aeneas through the underworld, through a capacious world geography, visiting Constantinople, the Holy Lands, Troy, India, and China before coming to a certain high place. There the Sibyl calls a name in Greek, and a figure "estrange, mais n'y ot laidure" ("strange but without ugliness") (1.1580) descends from the sky. This being, whom the Sibyl identifies as "Ymaginacion", lets down a ladder wrought of an ingenious material called "Speculacioun" (11. 1645-48), fabulously light

Interfaces $8 \cdot 2021 \cdot$ pp. 7-13 $\cdot$ DOI 10.54103/interfaces-08-02 
3. I would like to thank Divna Manolova and Chiara D'Agostini for their insights into the Byzantine transmission of the Commentary, and D’Agostini in particular for drawing my attention to Planudes' epigrams. and portable, for the pair to climb. From its highest rung Christine looks down at the Earth below, evoking its image, "comme une petite pellote" ("like a small ball") (1.1703), to critique the moral state of a world divided by war.

Both Chaucer and Christine de Pizan model their cosmic visions on the Somnium Scipionis ("Dream of Scipio"), which concludes Cicero's dialogue on Roman politics De re publica (54-51 BCE). On the eve of battle, the young Roman soldier Scipio dreams that he is visited by his departed grandfather, the famous general Scipio Africanus, and taken to a high place among the stars to look on the Roman Empire in its entirety and hear a lesson in cosmic and political order. Scipio's dream was the narrative space for a digression on the nature and structure of the physical universe, as the elder Scipio, the prototype of Chaucer and Christine's knowledgeable chaperones, points out to the young soldier the stars, planets and Milky Way. These astronomical allusions were elaborated upon in the Commentarii in Somnium Scipionis ("Commentary on the Dream of Scipio") written by the Latin grammarian and philosopher Macrobius Ambrosius Theodosius (fl. c. 40o), which canonised the dream's cosmological teachings for the European Middle Ages. Macrobius's Commentary circulated widely in Latin manuscripts - both in extenso and in an abridgement of its cosmological contents - and was translated into Greek by the Greek Byzantine scholar Maximos Planudes (c.1260-c.1305), becoming one of the most widely read and influential works on the matter of both dreams and astronomy in the Middle Ages. ${ }^{3}$

The cosmic dream vision traversed medieval European literatures, taking with it a potent narrative means of placing a human observer among the stars, and establishing a perspective from which the whole world and its geography could be seen to "resolve into a single sphere" (Cohen and Elkins Tanton 8). The genre's facility for intellectual experimentation was appealing to both poets and natural philosophers. Boethius uses the dream vision in his Consolation of Philosophy (c.524) to convey a dialogue between his dream persona and Lady Philosophy, reprising Macrobius's description of the physical universe, while the natural philosopher Nicole Oresme ( $c$. 1320/25-1382) used a dream at the close of his Tractatus de commensurabilitate vel incommensurabilitate motuum celi ("Treatise on the Commensurability or Incommensurability of the Heavenly Motions") to advance a pair of parallel orations by Arithmetic and Geometry theorising the planets' revolutionary motions (Kruger 141-

Interfaces $8 \cdot 2021 \cdot$ pp. 7-13 
49). Three centuries later, the form was adapted by Johannes Kepler, whose Somnium ("The Dream"), published posthumously in 1634, uses a dream to send a young astronomer to the moon, and develop a detailed mathematical description of how the Earth might look from its surface. The cosmic dream vision was a mobile and adaptive form that provided thinkers with a narrative space for intellectual experimentation, an imaginative means of freeing the intellect to achieve an elevated perspective on the Earth and its cosmic environment.

The cosmic dream vision was not only, however, an inventive means for writing about astronomy. Macrobius's Commentary was not written solely, or perhaps even primarily, as a treatise on cosmology, but as a work of literary criticism; its aim to demonstrate that Cicero and Virgil, whom Macrobius calls "the authors of our vocabulary" (1.15.10) and "the two founders of Roman eloquence" (2.5.7), did not contradict one another in their descriptions of the cosmos. Macrobius's astronomical explanations, that is, were calibrated precisely towards enabling a more receptive reading of poetry. Authors who subsequently developed Cicero's astronomical imagery tended also to inherit this preoccupation with poetics and literary production. As Kathryn L. Lynch has shown, the philosophical dream vision possessed a remarkable propensity for literary self-consciousness, most visible in its intense and allusive engagement with its literary precursors, most notably in the visions of Cicero, Boethius, and Dante (Lynch 2). In the House of Fame, Chaucer uses the dream vision to explore his relation to Classical authority as a poet writing in the vernacular, his eagle demonstrating through his reading of the skies that keener astronomical awareness can enable a more receptive reading of literature (11. 1008-10). Planudes, who translated Macrobius's Commentary into Greek, similarly couples the elevated perspective on the Earth with literary criticism in one of his epigrams on Claudius Ptolemy's Geography, in which he exalts Ptolemy's geometrical means of describing the "entire round curve of the earthly world" (1.2) above the "false verses and strange myths" (1.23) of poets (Pontani 195, 199-200). The histories of astronomy and literary criticism are more mutually constitutive, and characterised by a far greater degree of parity and interaction, than is generally recognised.

Astronomy and literary criticism are the twin themes explored in this issue of Interfaces. Its essays emerge from an interdisciplinary symposium that took place in August 2018, hosted by the Centre for Medieval Literature (Syddansk Universitet and the University of 
York). We assembled on the Swedish island of Hven, positioned in the sound between Denmark and Sweden, which has long been an important place in the histories of both literature and science. It was on Hven that the Danish astronomer Tycho Brahe had his observatory Uraniborg, a sumptuous research palace (at the time of its building, $1-4 \%$ of the Danish national budget was directed into Brahe's research) where Brahe astronomically described - for the first time the appearance of a new star, or nova, in the night sky. Hven also features as the setting of the early chapters of Johannes Kepler's Somni$u m$, his Icelandic protagonist acquiring an understanding of the new astronomy at Brahe's school before returning to Iceland and, with his mother's magical assistance, conversing with a daemon about how the Earth might look when viewed from the moon. Our meeting was also timely. The symposium marked the half-centenary of Earthrise (1968), among the earliest - and certainly the most famous - images of the Earth taken from the moon's surface. The experience of looking up at the stars, and eventually looking down on the Earth from a place among them, has often been co-opted into triumphalist narratives of scientific and cultural progress, with advances in science - whether the Copernican moment of the sixteenth century or the Apollo moment of the twentieth - credited with transforming our thinking about the Earth and its cosmic position in ways that were previously unimaginable. Somnium and Earthrise, seventeenthand twentieth-century views of the Earth from the moon's surface, challenged us to rethink the periodisations that frame the histories of literature and science. The four essays assembled here examine critical matters at the intersection between literature and science in four remarkable works, bearing witness to the relations between the two in moments between the ninth and twenty-first centuries.

Within the Middle Ages, this special issue examines two astronomically-involved works, one from the ninth-century Latin West and another from fourteenth-century Byzantium. Tom McLeish and Mary Garrison's essay epitomises an integrated approach to research in the natural sciences and the humanities in a scrupulous dissection of an extraordinary exchange between Charlemagne and Alcuin of York. Charlemagne, while engaged in a series of battles in Saxony, writes to his adviser, Alcuin, querying what he sees as an irregularity in Mars's orbit. Though Charlemagne's original letters are lost, Alcuin's two replies, written sometime in 798 , constitute the most detailed examination then written of apparent retrograde motion, the 
mechanism by which a planet appears temporarily to reverse direction in its orbit around the Earth. McLeish and Garrison's examination of this remarkable correspondence reveals the deep astronomical interest of not only a scholar and clergyman, but of a king and emperor, who, embroiled in battle and apparently keeping watch on the skies, may have been especially troubled by apparent irregularities in the planet of the god of war. The depth of astronomical speculation and enquiry that characterises medieval thought is a through line of this collection, brought to the fore in Divna Manolova's essay. Manolova examines the lunar theory of the fourteenth-century Byzantine scholar Demetrios Triklinios, who produced the earliest known detailed drawings of the moon's surface. Triklinios conceptualises the moon as a great mirror, applying his considerable optical knowledge to thinking about how the dark shapes on its surface might reveal to the observer the terrestrial geography of the known world. Manolova demonstrates how a Byzantine scholar looked to the moon's pale orb to see the Earth, and on it the Empire to which he belonged reflected back at a cosmic scale.

Turning to the seventeenth century, we examine two works that focalise the moon and our imaginative attachments to it. The conceptualisation of the moon as a place from which to see the Earth animates Kepler's Somnium, a thought experiment that, some three centuries before the photograph Earthrise, places a young astronomer on the moon to think imaginatively about what the Earth would look like from its surface. Victoria Flood's essay opens up the Somnium through an exploration of Kepler's familiarity with early modern witch theory. Although Kepler's biographers have called attention to the mathematician's involvement in his mother's witch trial, the broader influence of early modern witch-theory on Kepler's writings has been largely overlooked. Flood shows us how Kepler's daemon - the supernatural entity he conjures to take his astronomer's gaze to the moon's surface - relates to the writings of contemporary European demonologists and witch theorists, demonstrating that such works constitute parallels and likely sources for Kepler's translunar voyage. Matthew Francis's essay sheds light on his own poetic retelling of Francis Godwin's The Man in the Moone (1638), published in his 2013 collection Muscovy, in which a Spanish explorer, taking inspiration from the Travels of Sir John Mandeville, voyages to the moon and describes its unique flora and its otherworldly yet Christian inhabitants. Francis's poetic retelling of Godwin's goose-drawn ascent into the sky captures the triplicate sense of the moon as an object of scientific study, a destination, and 
4. On the place-making practices of planetary scientists, see Messeri.

5. On medievalisms in planetary nomenclature see Kedwards.
6. My thanks to Kristin Bourassa, for bringing Christine de Pizan's Chemin to my attention, and to all participants at the conference Interstellar Skies: The Lunar Passage in Literature through the Ages (Hven, 2018), for the early conversations that enriched this collection. a poetic figure. As he nears his destination, the lunar voyager's realisation that "the moon became a place" reveals the strong role that literature can play in making the cosmic knowable.

The relations between premodern literatures and astronomy are far greater, and more poignant to our own times, than we might suppose. Medieval imagery permeates the ways in which we conceptualise space and its exploration today. In the last fifty years of space history, more than 7000 names have been assigned to mountains, volcanoes, craters, and other features on planets and moons in our solar system. These names, assigned by the International Astronomical Union (IAU), are used by planetary scientists in their post-mission analysis of images from space probes, orbiters, and landers, and help us to think about distant planets not simply as astronomical 'data' - as faraway formations of rock and ice - but as 'worlds.' Modern day astronomers and planetary scientists draw the preponderance of these names from historical European cultures and mythologies, many of them emanating from the European Middle Ages. ${ }^{5}$ Chaucer, for example, lends his name to a crater, $45.48 \mathrm{~km}$ in diameter, on the far side of Earth's moon, while Arthur, Merlin, and Tintagil Catena, among other names adapted from Thomas Malory's Le Morte d'Arthur (c.1470), attach to craters and other geological features on Saturn's moon Mimas. Such names work to draw new worlds into the realm of human experience and culture, but they can also, in their overwhelming reliance on specifically western European historical imagery, replicate its prejudices. Saturn's moon Iapetus, for example, in distinguishing lighter regions from dark, takes its names from the eleventh-century Chanson de Roland, twinning the moon's striking twotone colouration, troublingly, with the poem's racialised distinction between the Franks and their monstered Muslim adversaries. While we might look up to space expecting to see visions of humanity's future, then, our solar system might already better resemble its past.

The essays presented in this special issue traverse the usual periodisations that frame the histories of literature and science to free the experience of looking up towards the stars, and eventually back down at the Earth from a place among them, from the broader narratives of scientific progress to which they are often assigned. Their perspectives on literature and astronomical subjects illuminate the histories of both, and bring us closer to understanding the historical construction of our own developing relationship with the universe. ${ }^{6}$ 
Bibliography

Chaucer, Geffrey. The Riverside

Chaucer, $3^{\text {rd }}$ edition. Ed. Larry D.

Benson. Boston: Houghton

Mifflin, 1987.

Christine de Pizan. Le Chemin de

Longue Étude. Ed. Andrea

Tarnowski. Paris: Librairie

Générale Française, 2000.

Coletti, Theresa. "Paths of Long

Study': Reading Chaucer and

Christine de Pizan in Tandem."

Studies in the Age of Chaucer 28

(2006): 1-40.

Cohen, Jeffrey Jerome and Linda $\mathrm{T}$.

Elkins-Tanton. Earth. New York:

Bloomsbury, 2017.

Kedwards, Dale. "Writing Fu-

tures". Reception and Reinvention:

Old Norse in Time and Space. 2021,

online exhibition.

Kruger, Steven F. Dreaming in the Middle Ages. Cambridge: Cambridge University Press, 1992.
Lynch, Kathryn L. The High

Medieval Dream Vision. Stanford: Stanford University Press, 1988.

Maus de Rolley, Thibaut. Élévations: L'écriture du voyage aérien à la Renaissance. Geneva: Droz, 2011. Messeri, Lisa. Placing Outer Space: An Earthly Ethnography of Other Worlds. Durham and London: Duke University Press, 2016.

Pontani, Filippomaria. "The World on a Fingernail: An Unknown Byzantine Map, Planudes, and Ptolemy." Traditio 65 (2010): 177-200.

Swinford, Dean. Through the Daemon's Gate: Kepler's Somnium. Medieval Dream Narratives, and the Polysemy of Allegorical Motifs. London: Routledge, 2006.

---. "Stellification and Poetic Ascent in the House of Fame." Modern Philology 111,1 (2013): 1-22. 